\title{
Innovate forms of project financing under the conditions of globalization
}

\author{
Erika Kovalova ${ }^{1}$, and Monika Poradova ${ }^{1, *}$ \\ ${ }^{1}$ University of Zilina, Faculty of Operation and Economics of Transport and Communications, \\ Department of Economics, Univerzitna 1, 01026 Zilina, Slovakia
}

\begin{abstract}
.
Research background: Innovative approaches to financing innovative projects are a very important part of innovation and project management in the current global environment, given the rapid pace of the market. The article submitted consists of four parts. The first part deals with the issue of project financing as well as innovative approaches to project financing. The second part describes them as current forms of financing in the form of individual forms of financing for innovative projects, but also as a combined form of financing for innovative projects with classic forms of internal and external financial resources. The third part of the article consists of an analysis of market developments, the volume of countries using innovative forms of crowdfunding project financing. Part three also includes a discussion. The fourth part deals with conclusions on the subject.

Purpose of the article: To describe innovative forms of project funding in a global innovation environment through entrepreneurial angels and crowdfunding. One of the objectives of the present article is to analyses the global development of the market, the volume of countries using innovative forms of project financing through crowdfunding.

Methods: In the processing of the present paper, a descriptive method, analysis, mathematical and statistical methods, graphic methods, comparison and synthesis were used.

Findings \& Value added: Will provide an overview of the global market for crowdfunding. It includes financing models such as P2P consumer credit and P2P business loans, real estate crowdfunding, invoice trading, balance sheet loans, etc.
\end{abstract}

Keywords: project financing, global environment, innovative management, crowdfunding, business angels

JEL Classification: G20; N20; O30

*Corresponding author: monika.poradova@,fpedas.uniza.sk 


\section{Introduction}

In today's global environment on the market is dominated by a model of technology dependence and mechanisation. They lead to a high level of production per production unit and hence high capital investment in innovation. With the increase in computing power, there has been an acceleration in the pace at which we build on new information technologies. The pace of change in the global environment puts pressure on businesses but also on customers to create increasingly sophisticated innovations for which to implement. Given their size, it is essential to use methods of managing large processes. [1]

Project management is considered to be one of the successful and widespread methods of managing large-scale activities of the innovation process. [2] Project management is a method used for planning and carrying out complex activities, which in terms of the innovation process represents its first part of the creation of Inventive. Projects are also characterised by a number of tasks, with the participation of several or more persons or working groups creating a complex system, with a view to achieving synergies of all the innovation capacity entering the project, which consists of the above-mentioned resources such as people, know-how, but also material equipment and others. [3]

The project may therefore be the development of a new product or service. It also takes a change in the organisation of the business or management style, which, from the point of view of the innovation process, is part of the creation of innovation in connection with its phases. [4] It follows from the foregoing that the project has the character of a process where, during its existence, it develops and goes through several phases. From the definition, through planning, organisation, control and completion, it follows and is closely linked to the part of the market making characteristic of innovation processes. [5] At the different stages of the project, the project resources are gradually involved. From purely ideological inputs to full use of all physical and material means of the innovation capacity of the project itself. In the gradual generation of project outputs that have the character of results of management performance and self-innovation within the framework of the innovation process, which is the main management of these activities, whether in project management or innovation management. [6], [7] This shows that the complexity of the different phases is a gradual and very closely interconnected interaction of individual processes. Therefore, in order to respect the interactions, involvement, feasibility, timing, orientation as well as other attributes of successful project completion, it is necessary to follow the procedures and tools specific to the different phases of project management. However, the whole process of project and innovation management is, among other factors, very conditional on funding, which is often the most serious factor in the implementation of innovation. [4] That is why we will focus on innovative approaches to funding opportunities.

\subsection{Innovative approaches to project financing}

Characterise project financing as a process of obtaining financial resources for the implementation of projects. The size and structure of the necessary capital are derived from the financial needs of the project and the financial resources that the project manager can obtain under the conditions. [8] We know from the theory of financial management different ways of financing, which are also used for project financing. In general, project financing combines different funding methods, which we divide into internal and external. [9] Inert sources include profit, provisions, depreciation. We divide external sources of funding into our own and foreign sources. At the same time, we divide foreign resources into classic, alternative and innovative ones. Among the classics are mainly credit. 
Alternatively, factoring, leasing, franchising, etc. Innovative resources include crowdfunding and business angels. [10]

The mentioned methods of financing are described by financial management. So far, little attention has been paid to innovative ways of financing. [11] Therefore, in the presented article we will deal in more detail with innovative forms of project financing.

\section{Methods}

The presented article deals with the issue of innovative forms of financing projects implementing innovations through business angels and crowdfunding. [12] It describes them as current forms of financing in the form of individual forms of financing innovative projects but also as a combined form of financing innovative projects with the classic forms of internal and external financial resources.

\subsection{Crowdfunding}

As reported by the crowdfunding is one of the emerging alternative forms of funding. They bring together directly those who have the funds at their disposal and want to lend or invest them with those who need the funds to finance a particular innovation project. Crowdfunding works on the principle of collecting smaller individual contributions from a large number of people, mostly via the Internet. Through crowdfunding, different types of innovation projects can be funded. Whether it's works of art, public projects, innovation, research and development or other business plans. On the one hand, there is a person with an idea for a project who prepares a crowdfunding campaign and we call it the owner of an innovation project. On the other hand, these are people who give money to carry out this inventive and call them contributors.

For crowdfunding purposes, internet crowdfunding platforms are set up where individual innovation projects are presented. This form allows ordinary people to carry out their projects, but they must meet the condition of interest to the general public. In Slovakia crowdfunding is only in its inception. Crowdfunding works on six different model forms, based on:

- remuneration - In this model, the contributor earns it in exchange for funding, a certain good or service,

- pre-sale of products - when the project owner collects funds for the development and production of a future product and contributors order it in advance with their contribution,

- profit sharing - when some crowdfunded projects offer a share of future profits from their business or from royalties and royalties,

- loan model - where direct loans - the so-called peer-to-peer loans - are a financial crowdfunding model in which campaign owners take the position of borrowers and contributors to act as their creditors. Borrowers can be businesses or individuals, and their projects range from social to business,

- securities - when crowdfunding takes the form of investments in securities. This model of crowdfunding is one of the slowest growing, as there are also the most barriers. Businesses have to give up part of the capital, there is a risk for investors to lose all their money, there are regulatory restrictions, a large number of shareholders must be managed. [13]

Crowdfunding involves the cooperation of three entities:

- Crowdfunding platform, resp. its operator - it is an entity that creates and operates a platform that connects the demand for funding of a particular project with persons willing to provide funding for this purpose. Supporters can decide which project they are interested in financially supporting. The crowdfunding platform usually works on an online basis and 
usually provides a payment interface. It offers these services itself or through third parties. The operator determines the conditions of operation of the platform.

- Supporters, resp. Investors - these are persons who individually provide a relatively small amount of funds in order to collectively collect a predetermined amount to support the financing of a particular project

- Project owners - these are people who ask supporters to fund their projects.

In the context of the current global financial ecosystem for businesses, crowdfunding can be an opportunity for entrepreneurs to obtain finance for their inventions. Crowdfunding thus contributes to bridging the global financing gap for companies and their innovative projects and complements funding sources. Crowdfunding offers contributors the opportunity to interact and engage more in the project, creating a sense of community and social cohesion. Crowdfunding financial models can create an additional investment opportunity where investors communicate and have direct contact with the creators of an innovation project

\subsection{Business angels}

Entrepreneurial angels, by the content of their vision, represent one of the possibilities of financing innovation. These are private individuals who are key to providing funding for the start-up phase of innovative businesses. Angels provide the so-called informal venture capital and invest it in innovative companies. However, they must have high growth potential already in the early and subsequent initial phase of the life cycle of companies and their innovation. They invest the funds in the company as a form of capital contribution and by increasing its capital. Business angels are investors who have already gained knowledge and experience in running their businesses and then try to find a suitable opportunity to invest their free capital.

Business angels are an important element in financing innovation. In addition to their capital contribution, they also pass on valuable advice and their managerial experience to their recipients, together with the possibility of using their business contacts. Thus, in addition to finance, they also provide them with know-how. For the beneficiaries, this means a huge benefit, because also especially in terms of insufficient managerial experience of the company. As a result, many businesses are unable to do business for more than five years. The main goal of business angels is to inspire and activate people to do business. At the same time, improve the image of entrepreneurship by promoting positive business models and innovation. Facilitate their access to capital through a network of business angels and, last but not least, constantly bring new benefits for business angels. [14]

A project that can apply for an investor should meet the following criteria: product development (product, service) is completed or is very close to completion. The product already has customers or potential customers who have shown a demonstrable interest. The entrepreneur has already invested time and his own money in the project. The entrepreneur has a team capable of realizing the intention. The most important investor criterion for projects is the high growth potential of business plans.

One of the aims of this article is to analyse the development of the global market, the volume of countries using innovative forms of project financing through crowdfunding. The three countries dominating the world crowdfunding market are still China, the United States and the United Kingdom. The USA and the United Kingdom still show impressive growth rates of $42.4 \%$ and $30.7 \%$, respectively, while the volume of Chinese funding fell by $-39.9 \%$. However, China is still the world market leader with a market share of $70.7 \%$. They are followed by the USA with $20.0 \%$ and the United Kingdom with $3.4 \%$. The list 
also includes countries such as the Netherlands, Indonesia, Germany, Australia, Japan, France and Canada - all with significantly smaller market shares.

This article will provide an overview of the global crowdfunding market, which includes financing models such as $\mathrm{P} 2 \mathrm{P}$ consumer loans and P2P business loans. Real estate crowdfunding, invoice trading, balance sheet loans, crowdfunding equity. Crowdfundingbased rewards, crowdfunding-based donations and more.

\section{Results and Discussion}

The data were collected through an annually distributed survey, so the latest available data, including the calendar year 2018. The data were given in the local currencies of the platforms, so all data were converted into euros using the historical average exchange rate for that year.

In figure 1 is a graph with a rounded number of statistics on the overall development of the world market in the volumes of crowdfunding funding from 2015 to 2018.

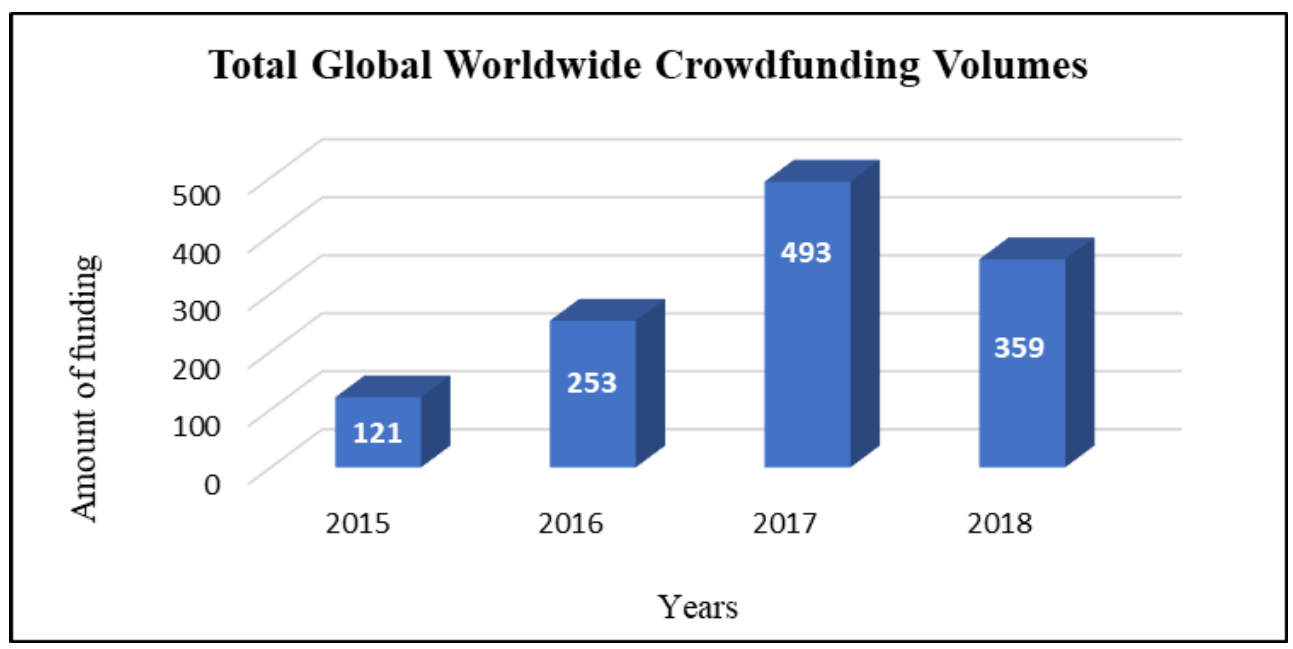

Fig. 1. Total global worldwide crowdfunding volumes.

It is worth mentioning that for the first time since the beginning of data collection, we are experiencing negative global growth in 2018. After growing by $108.6 \%$ in 2016 and $44.5 \%$ in 2017 , the crowdfunding market decreased by $-27.3 \%$ from $€ 493$ billion in 2017 to $€ 359$ billion in 2018. However, this can be largely attributed to the large decline in crowdfunding activities in China, which in 2017 accounted for $85.5 \%$ of the world market. The decline in Chinese crowdfunding activities can be largely explained: tighter regulation in China and widespread fraud. If we remove China from the data, we get a completely different image, which is shown in figure 2. 


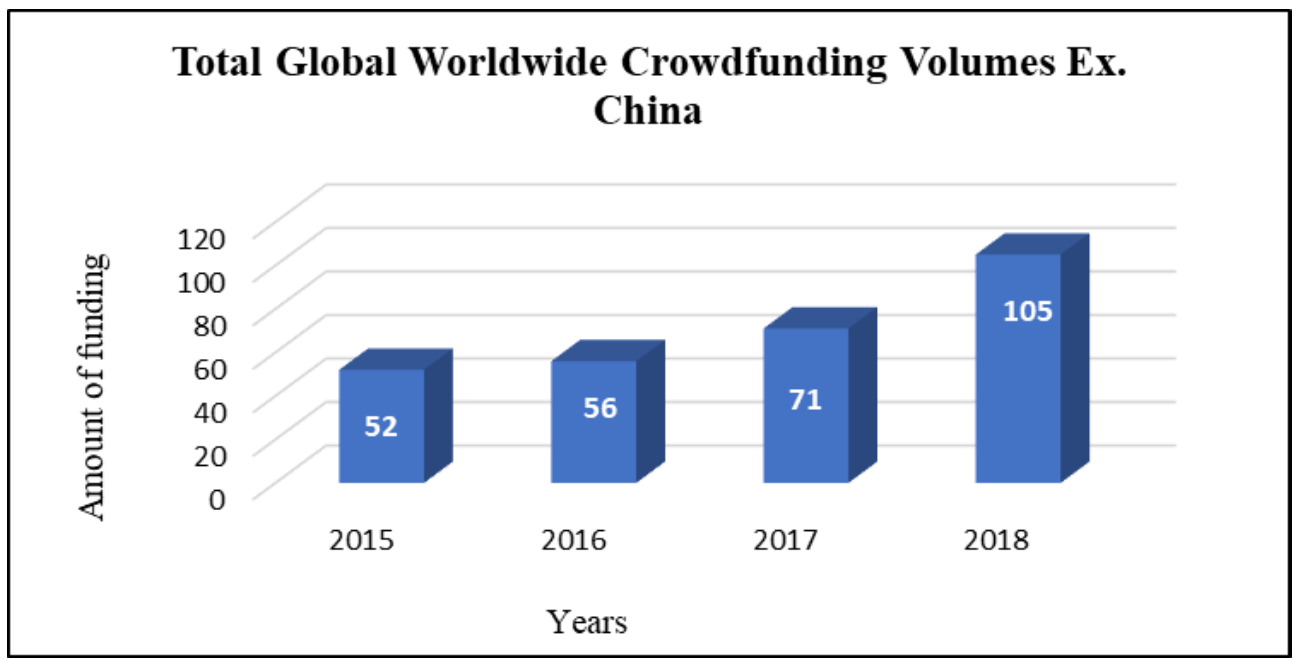

Fig. 2. Total global worldwide crowdfunding volumes ex. China.

The reason is that China still accounted for $71 \%$ of funding in 2018 . Without China, we get the picture of a smaller market, but a market with stable growth. Instead of declining by $-27.3 \%$, the non-Chinese market grew by $48.3 \%$ from EUR 71 billion in 2017 to EUR 105 billion in 2018. In comparison, the market grew approx. by $6.8 \%$ in 2016 and by $277 \%$ in 2017.

\subsection{Worldwide Crowdfunding Statistics by Business Model}

As crowdfunding is still a relatively new phenomenon, there is not always consistency in how different terms are used and defined in research. However, group funding can be broadly divided into four main categories: Debt-Based Crowdfunding, Stock-Based Crowdfunding, Remuneration-Based Crowdfunding, Donation-Based Crowdfunding.

Due to the dominant position of the debt category, it is useful to further break down the funds, which are shown in the following figure 3. 


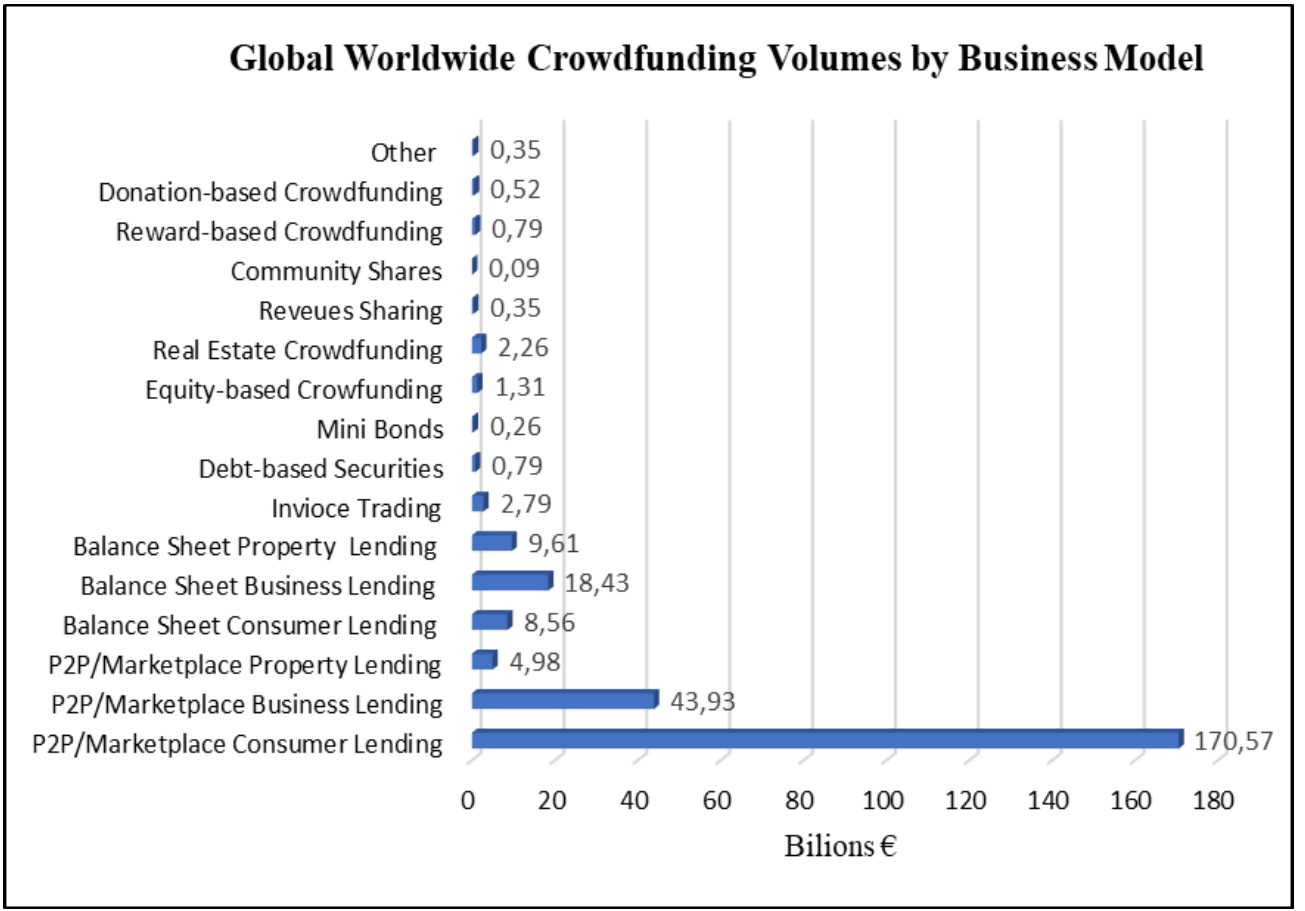

Fig. 3. Global worldwide crowdfunding volumes by business model.

From figure 4 we can see that more than $80 \%$ of funding volumes come from peer-topeer business lending and peer-to-peer consumer lending. Peer-to-peer consumer loans, with total funding of $€ 170.57$ billion, have a dominant market position. This is mainly due to the Chinese market, which draws $75.8 \%$ of its group financing from peer-to-peer consumer loans. Further on the list after P2P / consumer loans on the market and P2P / market loans for business we find three models of balance sheet lending, followed by $\mathrm{P} 2 \mathrm{P} /$ market real estate lending and invoice trading. The list also includes real estate crowdfunding, which is marked with $2,26 \%$ of global crowdfunding volumes. Mass real estate financing is also mentioned. With equity-based equity financing with $0.35 \%$ of global volumes. If we remove China from the data again, we get a completely different picture, which is shown in figure 4. 


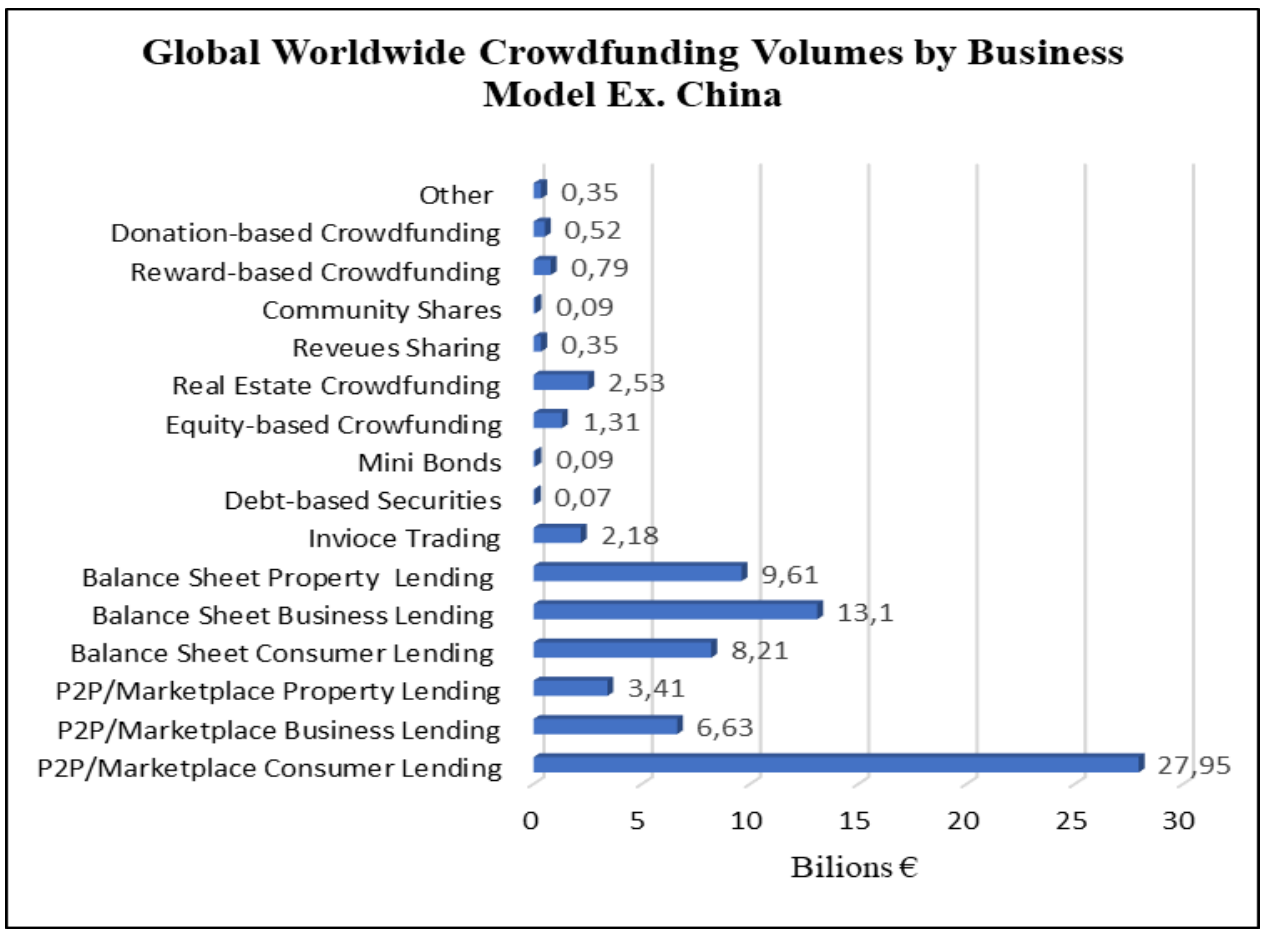

Fig. 4. Global worldwide crowdfunding volumes by business model ex. China.

As can be seen from figure 4, in this case the removal of China from the data set will bring about some remarkable changes, especially within the debt category. $\mathrm{P} 2 \mathrm{P} /$ market consumer loans are still the largest business model in the dataset, but currently account for only $27.95 \%$ of global funding volumes. All three models of lending in the balance sheet outperformed loans within the P2P / marketplace business.

In table 1 lists the 15 countries with the largest market share in the crowdfunding sector. The table also shows the total global volume of crowdfunding funding, which consists of data from all 171 countries / territories that participated in the research.

Table 1. Global Top 30 Crowdfunding Volume by Country.

\begin{tabular}{|c|c|c|c|c|}
\hline Country & Rank & Volume/[€] & $\begin{array}{c}\text { Market } \\
\text { Share }\end{array}$ & $\begin{array}{c}\text { Yearly } \\
\text { Growth Rate }\end{array}$ \\
\hline China & $1(1)$ & $188,119,116,024.45$ & $70.73 \%$ & $-39.88 \%$ \\
\hline United States & $2(2)$ & $53,392,451,074.24$ & $20.07 \%$ & $42.93 \%$ \\
\hline United Kingdom & $3(3)$ & $9,054,925,247.16$ & $3.40 \%$ & $31.04 \%$ \\
\hline Netherlands & $4(10)$ & $1,577,553,383.41$ & $0.59 \%$ & $480.72 \%$ \\
\hline Indonesia & $5(30)$ & $1,267,448,845.41$ & $0.48 \%$ & $1711.43 \%$ \\
\hline Germany & $6(8)$ & $1,114,586,438.43$ & $0.42 \%$ & $92.90 \%$ \\
\hline Australia & $7(4)$ & $1,018,817,509.17$ & $0.38 \%$ & $1.57 \%$ \\
\hline Japan & $8(9)$ & $938,652,282.97$ & $0.35 \%$ & $208.26 \%$ \\
\hline France & $9(7)$ & $814,963,255.9$ & $0.31 \%$ & $26.98 \%$ \\
\hline Canada & $10(6)$ & $794,109,428.82$ & $0.30 \%$ & $4.80 \%$ \\
\hline South Korea & $11(5)$ & $657,974,665.5$ & $0.25 \%$ & $-33.32 \%$ \\
\hline Israel & $12(\mathrm{New})$ & $633,910,218.34$ & $0.24 \%$ & $145.21 \%$ \\
\hline Brazil & $13(12)$ & $587,067,919.65$ & $0.22 \%$ & $149.30 \%$ \\
\hline India & $14(13)$ & $478,103,196,51$ & $0.18 \%$ & $103.82 \%$ \\
\hline Italy & $15(15)$ & $465,138,361.57$ & $0.17 \%$ & $99.16 \%$ \\
\hline
\end{tabular}


China still has the largest market share in the crowdfunding industry. She is followed by the United States, United Kingdom. In fourth place is the Netherlands. In fifth place among the countries with the largest market share within the industry is Indonesia.

For start-ups, crowdfunding is sometimes the only form of raising funds representing a commitment to contributors in the event of a positive impact on the financing of a project's project, which involves risk. The elimination of these risks associated with innovation fundraising projects is based on the trust of contributors. [15] This is enhanced by their direct involvement in projects within an open innovation system for the creation of inventions if they believe that their expected benefits will outweigh the potential costs. [16]

\section{Conclusion}

Innovative approaches to financing innovative projects are now an important part of innovation and project management, given the rapid pace of the market and the need to innovate products that take into account customer requirements in a short time and limited resources.

It is crowdfunding or business angels that ensure the potential greater success of these innovative projects, especially in terms of their ability to finance them, even if they combine these innovative methods of financing with traditional forms such as credit, leasing, etc.

The contribution is an output of the project VEGA 1/0619/20 Fundamental research of quantitative and qualitative determinants of enterprise innovation potential and innovation performance in relation to increasing its competitiveness.

\section{References}

1. Durana, P., Valaskova, K., Vagner, L., Zadnanova, S., Podhorska, I., Siekelova, A. (2020). Disclosure of strategic managers' factotum: Behavioral incentives of innovative business. International Journal of Financial Studies, 8, 17.

2. Ludbrook, F., Frajtova Michalikova, K., Musova, Z., Suler, P. (2019). Business models for sustainable innovation in industry 4.0: Smart manufacturing processes, digitalization of production systems, and data-driven decision making. Journal of SelfGovernance and Management Economics, 7(3), 21-26.

3. Zauskova, A., Lyakina, M., Tretyak, V., Miklencicova, R. (2020). Application of artificial neural networks to cost factors stimulating innovation - The case of Slovakia. Ekonomicko-manazerske spektrum, 14(1), 97-105.

4. Jakimowicz, A., Rzeczkowski, D. (2019). Do barriers to innovation impact changes in innovation activities of firms during business cycle? The effect of the Polish Green Island. Equilibrium. Quarterly Journal of Economics and Economic Policy, 14(4), 631676.

5. Hollowell, J. C., Kollar, B., Vrbka, J., Kovalova, E. (2019). Cognitive decision-making algorithms for sustainable manufacturing processes in Industry 4.0: Networked, smart, and responsive devices. Economics, Management, and Financial Markets, 14(4), 9-15.

6. Kral, P., Valjaskova, V., Janoskova, K. (2019). Quantitative approach to project portfolio management: proposal for Slovak companies. Oeconomia Copernicana, 10(4), 797-814. 
7. Bednar, P., Halaskova, M. (2018). Innovation performance and R\&D expenditures in Western European regions: divergence or convergence? Journal of International Studies, 11(1), 210-224.

8. Valaskova, K., Bartosova, V., Kubala, P. (2019). Behavioural aspects of the financial decision-making. Organizacija, 52(1), 22-32.

9. Bartosova, V., Kral, P. (2016). A methodological framework of financial analysis results objectification in the Slovak Republic, Proceedings of the 3rd International Conference on Business and Economics (pp. 189-197), 17.

10. Kachuriner, V., Hrushko, M. (2019). Formation of the innovative project financing model in modern conditions. Baltic Journal of Economic Studies, 5(2), 65-72.

11. Oliinyk, V., Kozmenko, O., Wiebe, I., Kozmenko, S. (2018). Optimal control over the process of innovative product diffusion: The case of Sony corporation. Economics and Sociology, 11(3), 265-285.

12. Durana, P., Zauskova, A., Vagner, L., \& Zadnanova, S. (2020). Earnings drivers of slovak manufacturers: Efficiency assessment of innovation management. Applied Sciences, 10(12), 4251.

13. Kral, P., Janoskova, K. (2015). Condition of Acceptability of Project Risk in Management of The Project Portfolio. Proceedings of the 15th International Scientific Conference on Globalization and its Socio-Economic Consequences (pp. 345-352), Rajecke Teplice, Slovak Republic.

14. Frias, K. M., Popovich, D. L., Duhan, D. F., Lusch, R. F. (2020). Perceived market risk in new ventures: A study of early-phase business angel investment screening. Journal of Macromarketing, 40(3), 339-354.

15. Zygmunt, A. (2019). External linkages and intellectual assets as indicators of firms' innovation activities: results from the Czech Republic and Poland. Oeconomia Copernicana, 10(2), 291-308.

16. Nica, E., Potcovaru, A. M., Hurdubei, R. E. (2019). Resilient cyber-physical systems and big data architectures in Industry 4.0: smart digital factories, automated production systems, and innovative sustainable business models. Economics, Management, and Financial Markets, 14(2), 46-51. 